\title{
Assessment of Vitamin D Level in Patients of Alopecia Areata
}

\begin{abstract}
Keywords: Vitamin D; Alopecia areata
\section{Abstract}

Alopecia Areata (AA) is a T cell-mediated autoimmune disease that causes inflammation around anagen-stage hair follicles. Insufficient levels of vitamin D have been implicated in a variety of autoimmune diseases. Previous reports have described the effects of vitamin $D$ on hair follicles. To evaluate the status of vitamin $D$ in patients with $A A$, and the relationship between vitamin $D$ levels and disease severity, a cross-sectional study of 23 patients with AA and 23 healthy controls was conducted. Serum vitamin D levels of the study group were determined by ELISA technique. Results revealed a significant difference between cases and control as regards $25(\mathrm{OH})$ vitamin $D$ level and its status. There is also a significant difference between $25(\mathrm{OH})$ vitamin $D$ status and the degree of AA but not with the pattern of AA. However, there is a non-significant difference in the $25(\mathrm{OH})$ vitamin $D$ status in all participants regarding age and sex of subjects. Accordingly, screening patients with AA for vitamin D deficiencies seems to be of value for the possibility of supplementing these patients with vitamin $D$
\end{abstract}

\section{Introduction}

Alopecia Areata (AA) is an autoimmune disease which is characterized by hair loss and can affect any hair-bearing area. Clinically, AA present with different clinical manifestations varying from reversible patchy hair loss to complete baldness or complete body hair loss. It affects approximately $1-2 \%$ of the general population [1].

Features of AA are caused by CD4+ and CD8+ T cells targeting hair follicles as an autoimmune-mediated skin disease attacks the hair follicle [2].

Vitamin D is known as a pro-hormone which is primarily synthesized in the skin. After synthesis, vitamin D binds Vitamin D-Binding Protein (DBP) and transports to the liver where it is hydroxylated to 25-Hydroxyvitamin D (25(OH)D). 1-alpha-hydroxylase (1a-OHase) enzyme converts $25(\mathrm{OH}) \mathrm{D}$ to 1,25-dihydroxyvitamin D3 $(1,25(\mathrm{OH}) 2 \mathrm{D} 3)$ in the kidney [3].

Vitamin $\mathrm{D}$ has been found to have immunoregulatory effects. $1,25(\mathrm{OH}) 2 \mathrm{D} 3$, which is the major form of vitamin $\mathrm{D}$, is a modulator of immune functions including activities of T-lymphocytes and B-lymphocytes as well as having role on immune responses [4].

The concentration of $1,25(\mathrm{OH}) 2 \mathrm{D} 3$ depends on an adequate supply of circulating $25(\mathrm{OH}) \mathrm{D}$ which is described as the primary indicator of vitamin D status [5]

Vitamin D deficiency was established as a risk factor for occurrence of some autoimmune diseases as SLE, Psoriasis and vitiligo [6].

It was said that the development of hair follicle depends on the Vitamin D Receptor (VDR) expression which correlates with increased differentiation of the follicle keratinocytes [7].

\section{Journal of}

\section{Clinical \& Investigative} Dermatology

\section{Enayat M. Attwa, Abdallah H. Kandil*, Waleed Elbalaat and Athar M. Samy}

Dermatology \& Venereology Department, Faculty of Medicine, Zagazig University, Egypt

\section{*Address for Correspondence}

Abdalla Kandil, Dermatology \& Venereology Department, Faculty of Medicine, Zagazig University, Egypt, Tel: 00201205115291; E-mail: ak.kandil@hotmail.com

Submission: 07 May, 2016

Accepted: 14 July, 2016

Published: 19 July, 2016

Copyright: () 2016 Attwa EM, et al. This is an open access article distributed under the Creative Commons Attribution License, which permits unrestricted use, distribution, and reproduction in any medium, provided the original work is properly cited.

The increased incidence of AA let us to search more for possible etiological factors. The relation between vitamin $\mathrm{D}$ deficiency and AA was mentioned recently in previous literature, so we try to confirm these results and see if there is possible relation between vitamin $\mathrm{D}$ deficiency and the pattern of AA.

\section{Patients and Methods}

This study was carried out at Dermatology, Venereology \& Andrology Department and Clinical Pathology Department, Faculty of medicine, Zagazig University during the period of April 2014 till November 2014. This study includes 46 subjects, 23 AA patients and 23 healthy controls. An informed written consent was signed by all participants and the study design was approved by the ethical committee, Faculty of medicine, Zagazig University.

\section{Patients}

Inclusion criteria: Male and female patients of different ages, duration and severity diagnosed clinically as AA.

Exclusion criteria: Patients currently taking nutritional supplement, pregnancy, drug usage and other associated diseases that could alter the level of vitamin D were excluded from the study, also patients and controls with systemic diseases affecting the hair, autoimmune diseases, or history of atopy.

\section{Methods}

All subjects in this study were subjected to history in the form of personal history, present illness history, as regards duration, number and site of patches, previous medications taken (in patients group), family history of AA or other skin or systemic disease affecting blood $25(\mathrm{OH}) \mathrm{D}$ level. General and dermatological clinical examination to exclude associated systemic diseases that may affect the blood $25(\mathrm{OH}) \mathrm{D}$ level, and to confirm the presence or absence of AA. Clinical assessment of the degree of Alopecia Areata was determined by Alopecia SALT score (Severity of Alopecia Tool score) as following [8]:

\section{S: Scalp hair loss}


Citation: Attawa EM, Kandil AH, Elbalaat W, Samy AM. Assessment of Vitamin D Level in Patients of Alopecia Areata. J Clin Investigat Dermatol. 2016;4(2): 4

$$
\begin{aligned}
& \text { S0 }=\text { no hair loss } \\
& \text { S1 }=<25 \% \text { hair loss } \\
& \text { S2 }=25-49 \% \text { hair loss } \\
& \text { S3 }=50-74 \% \text { hair loss } \\
& \text { S4 }=75-99 \% \text { hair loss } \\
& \text { S4a }=75-95 \% \text { hair loss } \\
& \text { S4b }=96-99 \% \text { hair loss } \\
& \text { S5 }=100 \% \text { hair loss }
\end{aligned}
$$

Classifications of patients were classified regarding the severity of AA according to SALT score into:

- Mild AA: patients who were S1 (<25\% hair loss)

- Moderate AA: patients who were S2 (25-49\% hair loss)

- Severe AA: patients who were S3, S4, and S5 (>50\% hair loss)

Patients were classified according to the pattern of AA into:

- Single patch

- Multiple patches

- Alopecia Totalis

- Alopecia Universalis

Serum 25 hydroxy vitamin D in cases and controls was measured by standard enzyme-linked immunosorbent assay (ELISA) method using (Calbiotech, USA) kits (Table 1) [9].

\begin{tabular}{|c|c|c|}
\hline Variable & Value & \\
\hline $\begin{array}{l}\text { Duration of the disease } \\
\text { (years) } \\
\text { mean } \pm S D \\
\text { Range }\end{array}$ & $\begin{array}{l}9.35 \pm 16.88 \\
0.1-60\end{array}$ & \\
\hline Family history & $\mathbf{N}$ & $\%$ \\
\hline $\begin{array}{l}-V E \\
+V E\end{array}$ & $\begin{array}{l}21 \\
2\end{array}$ & $\begin{array}{l}91.3 \\
8.7\end{array}$ \\
\hline $\begin{array}{l}\text { Degree: } \\
\text { S1(mild) } \\
\text { S2(moderate) } \\
\text { S3+S4+S5 (severe) }\end{array}$ & $\begin{array}{l}14 \\
3 \\
6\end{array}$ & $\begin{array}{l}61 \\
13 \\
26\end{array}$ \\
\hline $\begin{array}{l}\text { Pattern: } \\
\text { Single Patch } \\
\text { Multiple Patches } \\
\text { A. Totalis } \\
\text { A. Universalis }\end{array}$ & $\begin{array}{l}9 \\
11 \\
2 \\
1\end{array}$ & $\begin{array}{l}39.2 \\
47.8 \\
8.7 \\
4.3\end{array}$ \\
\hline
\end{tabular}

Assessment of vitamin D status: Vitamin D status was classified according to serum $25(\mathrm{OH})$ vitamin $\mathrm{D}$ concentrations into:

- Vitamin D deficiency: $25 \mathrm{OH}$ D concentration $<10 \mathrm{ng} / \mathrm{ml}$.

- Vitamin D insufficiency: 25 OH D concentration 10-30 ng/ml.

\begin{tabular}{|c|c|c|c|c|c|c|}
\hline Variable & \multicolumn{2}{|c|}{ Cases } & \multicolumn{2}{|c|}{ Controls } & Test & $P$ value \\
\hline $\begin{array}{l}\text { *Age:(years) } \\
\text { Range } \\
\text { Mean } \pm S D\end{array}$ & \multicolumn{2}{|c|}{$\begin{array}{l}9-41 \\
26.44 \pm 10.87\end{array}$} & \multicolumn{2}{|c|}{$\begin{array}{l}18-45 \\
29.39 \pm 8.10\end{array}$} & $\mathrm{~T}=-1.05$ & $\begin{array}{l}0.30 \\
\text { N.S }\end{array}$ \\
\hline \multirow{2}{*}{$\begin{array}{l}\text { *Sex: } \\
\text { Male } \\
\text { Female }\end{array}$} & $\mathrm{N}$ & $\%$ & $N$ & $\%$ & \multirow[b]{2}{*}{$x^{2}=0.09$} & \multirow[b]{2}{*}{$\begin{array}{l}0.76 \\
\text { N.S }\end{array}$} \\
\hline & $\begin{array}{l}15 \\
8\end{array}$ & $\begin{array}{l}65.2 \\
34.8\end{array}$ & $\begin{array}{l}14 \\
9\end{array}$ & $\begin{array}{l}60.9 \\
39.1\end{array}$ & & \\
\hline
\end{tabular}

- Vitamin D sufficiency: $25 \mathrm{OH}$ D concentration $>30 \mathrm{ng} / \mathrm{ml}$.

\section{Statistical analysis:}

Table 1: Medical history of cases

This table shows medical history of cases regarding duration of the disease, family history, degree and pattern of AA.
Table 2: Socio-demographic characters of controls and cases.

No significant difference between patients and control as regard age and sex of the subjects.

- The collected data were computerized and statistically analyzed using SPSS program (Statistical Package for Social Science) version 18.0.

- Chi square test was used to calculate difference between qualitative variables.

- Quantitative data were expressed as mean \pm SD (Standard deviation).

- Independent $\mathrm{T}$ test was used to calculate difference between quantitative variables in two groups.

- ANOVA F-test was used to calculate difference between quantitative variables in more than two groups.

- Pearson correlation coefficient used to calculate correlation between quantitative variables.

\section{Results}

No significant difference between cases and controls regarding age and sex of subjects, Table 2. Results revealed a significant difference between cases and control as regards $25(\mathrm{OH})$ vitamin D level and its status, Table 3. Also, there is a significant difference between $25(\mathrm{OH})$ vitamin D status and the degree of AA but not with the pattern of AA, Table 4. However, there is an on-significant difference in the $25(\mathrm{OH})$ vitamin $\mathrm{D}$ status in all participants regarding age and sex of subjects Table 5.

\section{Discussion}

Alopecia areata is an organ-specific autoimmune disease characterized by $\mathrm{T}$-cell infiltrates and cytokine production around anagen-stage hair follicles [10].

Autoimmunity in AA is strongly supported by clinical observations that patients with AA are often diagnosed with one or more other autoimmune disorders such as vitiligo, lupus erythematosus and Type I diabetes. In addition, the efficacy of various immunosuppressive agents including cyclosporine and systemic corticosteroids also suggest anautoimmune mechanism. Further, the Human Leukocyte Antigens (HLA) has been reported to play a major role in the etiology of autoimmunity. This specific hypothesis is confirmed by the increased expression of specific HLAs in AA patients such as HLADR, HLA-A, HLA-B, and HLA-C, which are rarely seen in healthy individuals as well as the identification of a number of genetic risk factors within various innate and adaptive immunity gene loci [11]. Cytokines including IL- $1 \alpha$, IL- $1 \beta$ and TNF- $\alpha$ may play an important role in the pathophysiology of AA. CD8+ T cells are considered to act as the effector cells with help from CD4+ T cells [12].

Vitamin D is a steroid hormone that plays an important role in 
Citation: Attawa EM, Kandil AH, Elbalaat W, Samy AM. Assessment of Vitamin D Level in Patients of Alopecia Areata. J Clin Investigat Dermatol. 2016;4(2): 4

ISSN: 2373-1044

Table 3: Comparison between cases and controls regarding serum 25(OH)D status and level.

\begin{tabular}{|c|c|c|c|c|c|c|}
\hline \multirow[b]{2}{*}{ Vit D status: } & \multicolumn{2}{|c|}{ Cases } & \multicolumn{2}{|c|}{ Controls } & \multirow{2}{*}{$x^{2}$} & \multirow{2}{*}{$P$ value } \\
\hline & $\mathbf{N}$ & $\%$ & $\mathbf{N}$ & $\%$ & & \\
\hline Deficient & 5 & 21.7 & 3 & 13 & \multirow{3}{*}{8.69} & \multirow{3}{*}{$0.01^{*}$} \\
\hline Insufficient & 16 & 69.6 & 9 & 39.1 & & \\
\hline Sufficient: & 2 & 8.7 & 11 & 47.8 & & \\
\hline \multicolumn{7}{|l|}{ Vit D Level: } \\
\hline $\begin{array}{l}{ }^{*} \text { Vit } \mathbf{D}(\mathbf{n g} / \mathbf{m l}): \\
\text { Range } \\
\text { mean } \pm S D\end{array}$ & \multicolumn{2}{|c|}{$\begin{array}{l}1-32 \\
14.13 \pm 8.72\end{array}$} & \multicolumn{2}{|c|}{$\begin{array}{l}9-50 \\
22.43 \pm 10.94\end{array}$} & -2.85 & $0.01^{*}$ \\
\hline
\end{tabular}

${ }^{*} \mathrm{P}$ value is significant if $<0.05$

Significant difference between patients and control as regard serum $25(\mathrm{OH}) \mathrm{D}$ level and status $(p=0.01)$.

calcium homeostasis and bone health. Its main source is endogenous synthesis in the skin which is induced by ultraviolet $B$ radiation. It can also be obtained exogenously through the diet [13].In the immune system, 1,25(OH)2D3 targets various immune cells, especially $\mathrm{T}$ lymphocytes and B lymphocytes, cytokines and modulates both innate and adaptive immune response [7].

It was said that VDR may play a vital role in the postnatal maintenance of the hair follicle. It is expressed in dermal papillae cells and in the epidermis of the hair follicle in varied degrees in correlation with the stages of the hair cycle [14].

A recent study demonstrated that the decreased expression of VDR in AA and alopecia universalis lesions is related to decreased expression of Wnt signaling pathway, which inhibits proliferation and differentiation of hair follicles and epidermal cells [15].

A recent systematic review found that vitamin D seems to play a beneficial role in the prevention of autoimmune disorders [16]. Organz-Molina et al. found a decreased level of vitamin $\mathrm{D}$ in patients with psoriasis [17]. While Beheshti et al. found a decreased level of vitamin $\mathrm{D}$ in patients with vitiligo [18].

The aim of this study was to evaluate the relation of Vitamin D in the pathogenesis of AA which may be helpful in its treatment.

The present work was performed on 23 patients with AA and 23 healthy controls to detect their serum $25(\mathrm{OH}) \mathrm{D}$ level.

The results showed a statistically significant decrease of mean serum 25(OH)D level among patients of AA $(14.13 \pm 8.72 \mathrm{ng} / \mathrm{ml})$ compared to control group $(22.43 \pm 10.94 \mathrm{ng} / \mathrm{ml})$ with $(\mathrm{P}$ value $=0.01)$.

Our results are parallel with the study made by (Yilmaz et al.) which showed a statistically significant difference between AA patients $(n=42)$ and control group $(n=42)$ regarding serum $D$ concentration $(\mathrm{P}<0.001)$ which suggested that vitamin $\mathrm{D}$ deficiency may have a role in the setting of AA [7]. Another study by Nassiri et al. investigated serum 25(OH)D level of 28 patients with AA and 44 healthy controls [19]. The median serum $25(\mathrm{OH}) \mathrm{D}$ was lower in patients with $\mathrm{AA}$ than controls although the difference was not statistically significant $(\mathrm{P}=0.07)$, also El-Mongy et al. ran a study on 70 cases of AA and 70 healthy controls, the study showed that serum $25(\mathrm{OH}) \mathrm{D}$ levels was significantly decreased in AA patients than in controls $(\mathrm{P}=0.023)$ [20].

Our results support the results of the study by Mahamid et al. who investigated 23 patients with AA and 23 healthy controls for serum 25(OH)D level [21]. A strong correlation between AA and vitamin $\mathrm{D}$ deficiency was found $(\mathrm{P}=0.02)$. This study also found an elevated C-reactive protein levels in the patients group which suggests inflammatory mechanisms apart from the proposed immune mechanism.

Cerman et al. investigated serum 25(OH)D level in 86 patients with AA, 31 patients with vitiligo and 58 healthy controls [12]. The prevalence of $25(\mathrm{OH}) \mathrm{D}$ deficiency was significantly higher in the group of patients of AA $(\mathrm{P}=0.001)$ than in the group of patients of vitiligo $(\mathrm{P}<0.001)$ compared with the group of healthy controls. These results link between the low vitamin $\mathrm{D}$ level and the occurrence of various autoimmune diseases such as AA, Vitiligo, SLE, DM, and Rheumatoid Arthritis. On the other hand, a study by D'Ovidio et al. made in Italy demonstrated the presence of insufficient level of $25(\mathrm{OH}) \mathrm{D}$ in patients with chronic and relapsing AA [22]. This study was done on 156 patients of AA and 148 healthy controls. The results confirmed that the level of vitamin D in AA patients was lower than controls although the results were not statistically significant $(\mathrm{P}=0.24)$. This may be due to the universal tendency to lower values of $25(\mathrm{OH}) \mathrm{D}$ even in the normal population in Italy due to lack of sun exposure.

In the present study, an insufficient level of vitamin $\mathrm{D}$ was more common in females (70.6\%) than in males $(48.3 \%)$, but it wasn't statistically significant, may be because the female participation in

Table 4: Comparison between $25(\mathrm{OH}) \mathrm{D}$ status in cases in relation to degree and pattern of $\mathrm{AA}$.

\begin{tabular}{|c|c|c|c|c|c|}
\hline Degree of AA & Deficient & Insufficient & Sufficient & $\begin{array}{c}\text { Test } \\
\mathrm{X} 2\end{array}$ & P Value \\
\hline $\begin{array}{c}\text { Mild } \\
(n=14)\end{array}$ & $\begin{array}{cc}\mathrm{N} & \% \\
1 & 7.1\end{array}$ & $\begin{array}{cc}N & \% \\
12 & 85.8\end{array}$ & $\begin{array}{lr}\mathrm{N} & \% \\
1 & 7.1\end{array}$ & & \\
\hline $\begin{array}{l}\text { Moderate } \\
\quad(n=3)\end{array}$ & 00 & $2 \quad 66.7$ & 133.3 & 11.91 & 0.02 \\
\hline $\begin{array}{l}\text { Sever } \\
(n=6)\end{array}$ & $\begin{array}{ll}4 & 66.7\end{array}$ & 233.3 & 00 & & SD \\
\hline \multicolumn{6}{|l|}{ Pattern } \\
\hline $\begin{array}{c}\text { Single } \\
(n=9)\end{array}$ & 111.1 & $7 \quad 77.8$ & 111.1 & & \\
\hline $\begin{array}{c}\text { Multiple } \\
(n=11)\end{array}$ & $2 \quad 18.2$ & 872.7 & 19.1 & & \\
\hline $\begin{array}{l}\text { A.Totalis } \\
(n=2)\end{array}$ & 150 & 150 & 00 & 5.32 & 0.5 \\
\hline $\begin{array}{l}\text { A. univ. } \\
(n=1)\end{array}$ & 1100 & 00 & 00 & & N5 \\
\hline
\end{tabular}

Significant difference between $25(\mathrm{OH})$ Vit $D$ status and degree of AA but no significant difference with the pattern of $A A$.

Table 5: Comparison between $25(\mathrm{OH}) \mathrm{D}$ status in all participants in relation to sex and age groups.

\begin{tabular}{|c|c|c|c|c|c|}
\hline \multirow[b]{2}{*}{ Sex } & Deficient & Insufficient & sufficient & \multirow{2}{*}{$\begin{array}{c}\text { Test } \\
\mathrm{X} 2\end{array}$} & \multirow[t]{2}{*}{ P Value } \\
\hline & $\%$ & $N \quad \%$ & $\mathrm{~N} \%$ & & \\
\hline Males & 827.6 & $14 \quad 48.3$ & $7 \quad 24.1$ & \multirow{2}{*}{5.69} & 0.06 \\
\hline Females & 00 & 1170.6 & $6 \quad 29.4$ & & N5 \\
\hline \multicolumn{6}{|l|}{ Age } \\
\hline $1-20 y$ & $218.1 \%$ & $763.6 \%$ & $2 \quad 18.1 \%$ & & 0.12 \\
\hline $21-40$ & $39.6 \%$ & $1754.8 \%$ & $1135.4 \%$ & 12.93 & N5 \\
\hline $41-50$ & $375 \%$ & $125 \%$ & $0 \quad 0$ & & \\
\hline
\end{tabular}

No significant difference between male and female and age groups as regard to $25(\mathrm{OH})$ Vit D status. 
Citation: Attawa EM, Kandil AH, Elbalaat W, Samy AM. Assessment of Vitamin D Level in Patients of Alopecia Areata. J Clin Investigat Dermatol. 2016;4(2): 4

ISSN: 2373-1044

this study was quite limited (34\% of cases and $39 \%$ of controls were females).

In the study of El-Mongy et al. the female participants in both cases $(n=33)$ and controls $(n=26)$ showed a significant lower vitamin $D$ level in compared with male participants in cases $(n=37)$ and controls $(n=44)$ with a $P$ value equaled (0.005) [19]. The same was noted in Cerman et al. with a P value equaled (0.041) this low vitamin $D$ level in females may be attributed to its consumption in pregnancy and lactation, and some social and cultural factors as the conservative dress of Egyptian women blocks exposure to sunlight which is the main source of vitamin D synthesis [12].

In the present study AA was classified to mild, moderate, and severe degrees according to (SALT) score. By comparing serum $25(\mathrm{OH}) \mathrm{D}$ status in the patients in relation to degree of $\mathrm{AA}$, we found a statistically significant difference between vitamin $\mathrm{D}$ status and degree of AA ( $\mathrm{P}=0.02)$.

This result met with the result of Cerman et al. who reported a significant negative correlation between the degree of AA by (SALT) score and serum $25(\mathrm{OH}) \mathrm{D}$ level in AA patients $(\mathrm{P}<0.001)$ [12].

Also, a more lowering of vitamin D level (below $10 \mathrm{ng} / \mathrm{ml}$ ) was noted in patients with extensive AA (Alopecia totalis and Alopecia universalis) when compared with its level in patients with patchy AA but this difference was not statistically significant. This may be due to limited number of patients with Alopecia totalis $(n=2)$ and Alopecia universalis $(n=1)$. This finding may support the role of vitamin $D$ in the evolution of AA.

Conversely, D'Ovidio et al. found no correlation between the severity of AA and serum 25(OH)D level [21]. This may be because methodological data such as the scoring of AA are not available in this study.

Regarding age, in the present study there was a tendency for the presence of a lower serum 25(OH)D level in the older age group (from 41-50 yrs) in all participants when compared to the younger age groups.

This may be because with increasing age, solar exposure is usually limited because of changes in lifestyle factors such as clothing and outdoor activity. Diet may also become less varied. Most importantly, however, the dermal production of vitamin $\mathrm{D}$ following a standard exposure to UVB light decreases with age because of atrophic skin changes with a reduced amount of its precursor. Also, the renal production of $1,25(\mathrm{OH}) 2 \mathrm{D}$ decreases because of diminishing renal function with age [23].

All of these findings points to the important role of vitamin $\mathrm{D}$ in the pathogenesis of AA and must be estimated in all patients of AA especially the females and the old patients which may open a new channel for its treatment.

\section{References}

1. Conteduca G, Rossi A, Megiorni F, Parodi A, Ferrera F, et al. (2014) Single nucleotide polymorphisms in the promoter regions of Foxp3 and ICOSLG genes are associated with alopecia areata. Clin Exp Med 14: 91-97.

2. Abdel Hafez HZ, Mahran AM, Hofny EM, Attallah DA, Sayed DS, et al. (2009) Alopecia areata is not associated with Helicobacter pylori. Indian J Dermatol 54: 17-19.

3. Baeke F, van Etten E, Gysemans C, Overbergh L, Mathieu C (2008) Vitamin $D$ signaling in immune-mediated disorders: evolving insights and therapeutic opportunities. Mol Aspects Med 29: 376-387.

4. Arnson $Y$, Amital H, Shoenfeld $Y$ (2007) Vitamin D and autoimmunity: new aetiological and therapeutic considerations. Ann Rheum Dis 66: 1137-1142.

5. Baeke F, Takiishi T, Korf H, Gysemans C, Mathieu C (2010) Vitamin D: modulator of the immune system. Curr Opin Pharmacol 10: 482-496.

6. Shoenfeld N, Amital H, Shoenfeld $Y$ (2009) The effect of melanism and vitamin D synthesis on the incidence of autoimmune disease. Nat Clin Pract Rheumatol 5: 99-105.

7. Yilmaz N, Serarslan G, Gokce C (2012) Vitamin D concentrations are decreased in patients with alopecia areata. Vitam Trace Elem 1: 105.

8. Bhat YJ Sajad P, Hassan I (2014) Etiopathogenesis of alopecia areata. Hair Ther Transplant 4: 123

9. Holick MF (2009) Vitamin D status: measurement, interpretation and clinical application. Ann Epidemoil 19: 73-78.

10. Wang E, McElwee KJ (2011) Etiopathogenesis of alopecia areata: why do our patients get it? Dermatol Ther 24: 337-347.

11. Seetharam KA (2013) Alopecia areata: an update. Indian J Dermatol Venero Leprol 79: 563-575.

12. Aksu Cerman A, Sariyaka Solak S, Kivanc Altunay I (2014) Vitamin D deficiency in alopecia areata. Br J Dermatol 170: 1299-1304.

13. Saleh HM, Abdel Fattah NS, Hamza HT (2013) Evaluation of serum 25-hydroxyvitamin $D$ levels in vitiligo patients with and without autoimmune diseases. Photodermatol Photoimmunol Photomed 29: 34-40.

14. Amor KT, Rashid RM, Mirmirani P (2010) Does D matter? The role of vitamin $\mathrm{D}$ in hair disorders and hair follicle cycling. Dermatol Online J 16: 3.

15. Lim YY, Kim SY, Kim HM, Li KS, Kim MN, et al. (2014) Potential relationship between the canonical Wnt signaling pathway and expression of the vitamin D receptor in alopecia. Clin Exp Dermatol 39: 368-375.

16. Antico A, Tampoia M, Tozzoli R, Bizzaro N (2012) Can supplementation with vitamin $D$ reduce the risk or modify the course of autoimmune diseases? A systematic review of the literature. Autoimmun Rev 12: 127-136.

17. Orgaz-Molina J, Magro-Checa C, Arrabal-Polo MA, Raya-Álvarez E, Naranjo $\mathrm{R}$, et al. (2014) Association of 25-hydroxyvitamin D with metabolic syndrome in patients with psoriasis: a case-control study. Acta Derm Venereol 94: 142145.

18. Beheshti A, Ghadami H, Barikani A, Haj Manouchehri F (2014) Assessment of vitamin D plasma levels in patients with vitiligo vulgaris. Acta Med Iran 52: 601-606.

19. Nassiri S, Saffarian Z and Younespour S (2013) Association of vitamin D level with alopecia areata. Iran J Dermatol 16: 1-5.

20. El-Mongy NN, El-Nabarawy E, Hassaan SA, Younis ER, Shaker O (2013) Serum 25-hydroxy vitamin D3 level in Egyptian patients with alopecia areata. J Egypt Dermatol Soc 10: 37-41.

21. Mahamid M, Abu-Elhija O, Samamra M, Mahamid A, Nseir W (2014) Association between Vitamin D levels and alopecia areata. Isr Med Assoc J 16: 367-370.

22. d'Ovidio R, Vessio M, d'Ovidio FD (2013) Reduced level of 25-hydroxyvitamin D in chronic/relapsing alopecia areata. Dermatoendocrinol 5: 271-273.

23. Mosekilde L (2005) Vitamin D and the elderly. Clin Endocrinol (Oxf) 62: 265 